\title{
Money functions in digital economy
}

\author{
Olga Mikhailovna Korobeynikova \\ Economic security and economy in agro-industry \\ department \\ Volgograd state agrarian university, \\ Volgograd, Russia \\ korobeinikov77@yandex.ru
}

\author{
Dmitry Aleksandrovich Korobeynikov \\ Economic security and economy in agro-industry \\ department \\ Volgograd state agrarian university, \\ Volgograd, Russia
}

\begin{abstract}
The article proves that digital technologies of money turnover evolution of money and money tools, development of the payment institutional infrastructure changed money turnover functioning and money functions specifications. Money functions are not static and can be changed according to innovations, conducted by elements of payment infrastructure. Money function specifications depend on the time money stays (static) within channels of payment systems and the time of movement (dynamic) of money along them. The article defined reasonable dependence of money movement velocity and the level of economic digitalization and development of the payment infrastructure for the stages of the formula 'money-commoditiesmoney'. The revealed trends and their dynamics indicate the diffusion of the classical function of money and derived functions due to transformation of the material form of money into the immaterial digital form.
\end{abstract}

Keywords - money; currency circulation, money turnover, functions of money; payment systems; digital economy

\section{INTRODUCTION}

In recent Russian financial science and practice, issues of money turnover modernization have been often discussed as an accelerator of economic development, sovereignization of the native payment system, providing acceleration for diffusion of technological and finance innovations, simultaneously minimizing economical, technological and geopolitical dependence risks that are critical in modern environment of foreign economic instability. Payment and settlement relations are formalized, but the fundamental theory of a subject and an object falls behind practical needs of money and currency circulation (O.M. Korobeynikova \& D.A. Korobeynikov, 2015).

We should pay special attention to money theories, which should be upgraded along with evolution of economic relations in the society, modernization of technological modes including the sphere of currency circulation. It is considered that "the best way to define money is describing specification of its functions" (E. J. Dolan \& D. Lindsay, 1994, p. 174), is studying the idea of money and its transformation from the point of view of functions that act as essence and are a representative of special aspects of money use.

\section{MATERIALS AND METHODS}

In the scientific papers of money theory founders and our contemporaries there is no universal idea in defining what money is, as well as no universal point of view about changing of functions of modern digital money and infrastructure elements of payment systems. That can be explained by the fact that "in different periods of history in different conditions some functions don't work anymore" (V.M. Usoskin, 2006).

J. Keynes investigated three functions of money: standard of value and means of payment, means of hoarding, global money (J.M. Keynes, 1999). Four different functions were classified by K. Knis (means of hoarding, standard of value, means of payment, medium of exchange). S. Fisher, R. Dornbush, R. Shmalenzy classified store of value, medium of exchange and means of payment, means of delayed payment, a unit of calculation. L. Miller, D. D. Van-Khuz considered medium of exchange, means of payment, store of value, a monetary unit). K. R. Macconell and S. Brue, excluding an independent function of means of payment, established only three functions of money: circulation, hoarding and standard of value. L. Harris also classifies three functions: means of circulation, units of calculation and conservation of value. $P$. E. Samuelson studied money, on the one hand, as a unit of calculation or standard of prices, and on the other - as medium of exchange (P. Samuelson, 1993).

In educational materials of Soviet and post-soviet union periods in Russia, K. Marks's approach is taken as an axiom. This approach considers money based on labor value classifying five functions according to logic and order of their performance: standard of value; medium of exchange; means of hoarding; means of payment; global money (K. Marks, 2013). The function of global money, founded by K. Marks for the closed socialistic economics today is often taken away as alien to modern money in the conditions of globalization (J.E. Stiglitz \& A. Bhattacharya, 1999), (M.L. Bech et al, 2008). A.M. Kosoy, using the K. Marks's approach, explains functional performance of money, classifying an additional sixth function, called 'standard of prices'. (A.M. Kosoj, 2005).

A.S. Selischev's approach to hierarchy of money functions within historical development is very interesting. At the basis of his hierarchy there is the postulate that money has immanent absolute liquidity, contributing to optimization of exchange relations having minimal money and time costs. A.S. Selischev classifies five main (according to K. Marks's idea) and five derived functions of money (productive, seigniorage, informative, regulating, institutional). $\mathrm{He}$ 
connects the performance of these functions with a level of society development. So, in modern highly developed economies, money has three main functions: standard of value, medium of exchange (payment) and means of hoarding. In less developed countries there are four functions (standard of value, medium of exchange, means of hoarding and means of payment); within time of validity of 'golden standard', all five functions act for 'peripheral' (A.S. Selishchev, 2012).

Today considering a new technological approach, it is evident that previously acting approaches to content and performance of different functions of money should be updated according to changing of economic relations, served by money, and changing of forms and types of money.

The investigation used general methodic scientific principles (unity of theory and practice, objectivity, complexity), as well as systemic approach to evaluation of aggregate picture of modern state of currency circulation within diffusion of digital innovations in the economics.

\section{RESULTS AND DISCUSSION}

We shall not describe differences in functions of money interpretation in detail, but we point out a general peculiarity of all theoretical approaches: performance of any function is explained from the point of view of acting for the certain scientific and technical level of development of monetary system and respective paying and settlement rules. Acting as an instrument that serves the economic relations, money and money turnover are sensitive to innovations and strictly follow the vector of economics development (and even are ahead and anticipate it). Modern digital payment services and systems changed features of functioning for cash and (especially) noncash money turnover. The main factor, influencing changes in money turnover and specifications of money functions, became hold-up time (statics) of money in the channels of payment systems and motion time (dynamics) of money along these channels.

Development of modern innovative payment systems makes it possible to rank money functions depending on changes in their content, we can classify the main functions as: 1) a function of money as medium of exchange, 2) a function of money as means of payment and derived functions, 3) a function of money as standard of value, 4) a function of money as store of value (value accumulation). Furthermore, innovative development of modern payment systems gives the new understanding of information, production, regulating institutional function of money.

\section{A. Money as means of exchange and payment}

Money as means of exchange provides services for differently directed movement of forwarded and paid values, this process is on-line synchronization of commodity and money flows. Digital payment technologies contribute to accelerating of monetary transactions and saving of accompanying direct and transaction expenses (Diana Dmitrievna Burkaltseva, Oleg Valerievich Boychenko, Olga Sergeevna Sivash, Nicholas Maksimovich Mazur, Snezhana
Anatolyevna Zotova, Aleksey Valeryevich Novikov, 2017).

The basic actual feature is money's function as means of payment. It is usually demonstrated by credit, stipulating the time lag between the commodity and money counter flows (A.S. Ovchinnikov et al, 2014). Before information technologies expanded, velocity and price of payments depended on variations of payments. Payments velocity of one form of settlements could vary for different regions. Subjects and objects of payment; the same situation was observed for direct and indirect (transaction) costs for payments. Modern payment systems consider velocity of payments and money on the stage of their delivery between the parties within the process of payoff function. Now there is the possibility of unification and standardization of money flows that minimizes some financial risks, allow plan and do benchmarking analyses. (A.V. Nemchenko et al, 2016).

The most part of money transactions have been recently done on the basis of bank electronic accounts; the most part of economist suppose that in our days, the functions of means of payment and means of exchange merge (V.I. Ionov, 2010).

Figure 1, represented in the shape of the matrix structure, demonstrates interpretation of the classical formula 'money commodity-money' within payment systems functioning with different money circulation velocity.

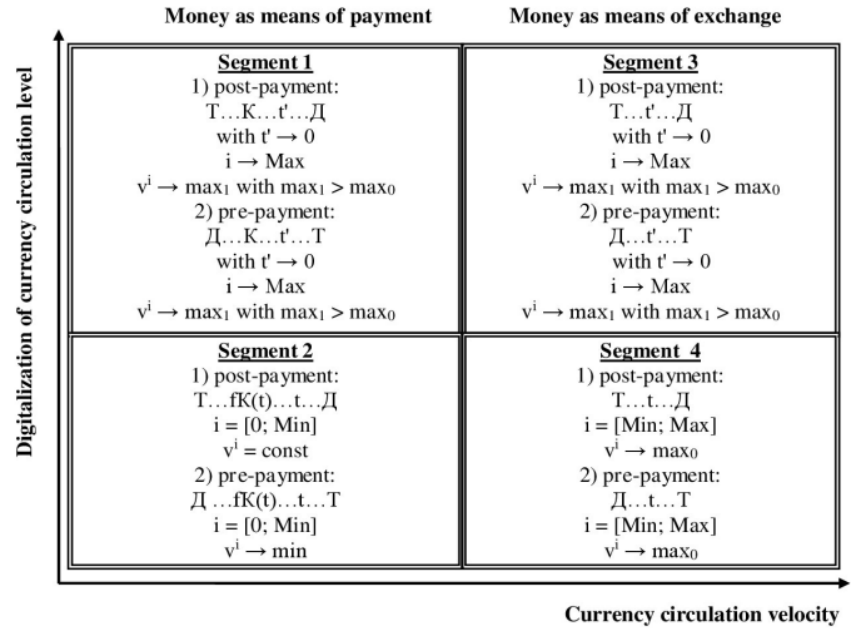

Fig. 1. Money functiions within digitalisation of money turnover

\section{The legend of the picture is:}

$T$ - commodities, works, services, changed for money via payment system;

$f K(t)$ - period of delay of the payment (credit) considering time expenses for payment;

$K-$ period of delay of the payment (credit) according to mutual agreement of the parties;

$t$ - time to deliver money from the payer to the payee considering poor level of money turnover digitalization;

$t^{\prime}$ - time to deliver money from the payer to the payee considering high level of money turnover digitalization;

Д- money to pay for the goods, works, services;

$i$ - information about money flow (aggregate scope of information for operations with cash and non-cash money and 
relevant and forwarding information);

$v^{i}-$ information transfer about the money flow velocity;

$\max _{0}-\quad$ maximally technologically possible index if

payment systems are not developed;

$\max _{1}-\quad$ maximally technologically possible index if payment systems are developed.

The matrix has got 4 variants of money functions for prepayment and post-payment.

Axis OX demonstrates dynamics of money turnover velocity, axis OY demonstrates dynamics of digital innovations expanding within money turnover that direct proportionality defines the money flow velocity.

Within segment 2, represented by formula T...fК $(\mathrm{t}) \ldots \mathrm{t} . . . Д$ or Д ...fК $(\mathrm{t}) \ldots \mathrm{t} . . . \mathrm{T}$, money turnover velocity is the lowest, has got two components, where the time element is considered the mostly:

1) $\mathrm{fK}(\mathrm{t})$ - functional dependence of credit lag between bargain and payment from time of providing delay considering transaction expenditures for payment. We can consider qualitative transaction expenditures as loses of time for searching alternative ways of payment and guarantees for their delivering, when we have to use non alternative forms of settlement, engaging additional guarantees of settlements and payment and other. In our case to the transactional expenses in quantity belong to additional commissions for money transactions, loses for slowing down the money turnover, necessity for an additional current position and other.

Thus, the fact of payment delay stipulates encumbrance as maximal expenses of time (comparing with other segments of matrix) for providing of this delay. On the stage of payment system formation, the time factor is certain constant; it is difficult to minimize it systemically.

2) $\mathrm{t}$ - time for payment. This is an initial index of basic time, needed for transformation of goods into money. Maximal values $t$ are demonstrated in early commodity-money relations and as they develop, the index t decreases.

Segment 1, specified by formulas Т...К...t'..Д or Д...К...t'...Т, demonstrates modification of the money function as means of payment when developing payment systems and relations to a modern level and higher, and according to V.A. Chelokov's opinion 'trade-off of individual circular movements of funds' of the member relations (V.A. Chelnokov, 2010, p. 19). From the previous variant, segment 1 differs in specification of credit delay and time of implementation of the function.

In this case payment delay $\mathrm{K}$ is totally defined by payers and payee contract conditions and that is why doesn't depend as in the previous case on transaction expenses for the payment.

For modern payment systems (first of all for electronic), the pre-payment variant with advancing of funds to the pre-paid payment instruments and actual receiving of paid value is mostly a common variant. In this case $K$ is crediting of the payee for the total pre-paid value sum, which can be greater than the indicated value of pre-paid values (for example, prepaid multiple fare ticket for public transport, pre-paid card of
Internet trading, e-wallets and so on). Thus this variant is closely connected with developing of the money function as mean of hoarding.

The advantages of the upper segment transactions for prepayment and post-payment is in minimal, tending to zero $t$,' time for the chain Т..Д. The higher the level of global coordination and standardization of payment systems is, the less time and other expenses we need for payment.

Comparing $1^{\text {st }}$ and $2^{\text {nd }}$ segments demonstrates the index of effect of money functioning optimization: $\Delta \mathrm{t}=\mathrm{t}^{\prime}-\mathrm{t}$. Thus the higher the territorial and operational level of payment systems development is, the more clear the acceleration effect of money turnover is displayed.

So, according to our opinion, the money function as an instrument of payment developing of the payment system becomes of high priority and dominating. E.F. Zhukov proves this opinion; he also draws attention to the fact that its role emerges with increasing of non-cash payments (Money, credit, banks, 2009, p. 18). Moreover, V. V. Ivanov, B. I. Sokolov and other authors pay attention to direct subordinate relation of functions, indicating that money development as an instrument of payment 'improves its other functions'. (Money, credit, banks, 2003, p. 29).

Segment 4, represented by formula T...t...Д (post-payment where the function of medium of exchange is classically expressed) or Д...t...Т (pre-payment), indicates that money functioning is the exchange environment when payment systems are not developed, as there is great dependence from circulation time $t$. At other equal conditions of quantitative instability of temporary index defines uncertainty, increased finance and commercial risks and great expensed of money turnover, because of that $t$ can be considered constant for the group of homogeneous transactions. It is impossible to optimize the derived index, that is, money turnover within indicated conditions.

Segment 3, represented by formula Т...t'...Д or Д...t'...Т with $\mathrm{t}^{\prime} \rightarrow 0$, indicated transformation of medium of the exchange function. Payment systems allow maximally decreasing money flow between a payer and a payee (Т...Д), eliminating $t$ influence on their economic interests. The main result of money circulation of digital development in this aspect is money circulation acceleration for individual members and in general, for the whole system. Foreground results of the money circulation area that functions as medium of exchange on the micro-level are saving of transaction and general money expenses of the payer and payee, decreasing need in credit resources, optimization of money flows of the money turnover process members. At the macro-level that main effect would be decreasing of cash flow, serving the accelerated turnover and respective growth of effectiveness of money unit turnover, circulating in economic.

Specific features of Д element (money, paid for the commodities, works, services) within the segments of matrix of money functions transformation is that in low (2nd and 4th) and upper (1st and 3nd) segments function qualitatively different money, not only form tools point of view, but from money essence point of view. 
Main money functions - exchange and payment - produce the derived functions - store of value and standard of value that are the result of main money functions at different stages of payment system development.

Indeed, development of the payment system caused implementation of the storage function, derived from medium of the exchange function, shown in pre-payment terms in the upper left segment of the matrix.

\section{B. Money as store of value}

The money function as store of value (value accumulation) is in accumulation of money on natural and legal persons' accounts within the banking system (S.K. Semenov, 2006). In modern payment systems, money acts mostly as a technical instrument, then as a saving asset because of fast circulation of money within certain accounts. Despite preserving absolute or high liquidity (depending on financial stability and sovereignty of money turnover of the country), at present moment the saving function of money is not actualized.

In retail payment systems, funds transfer is classified according to ways of transfer commencement and how a bank account is used for transfer using payment cards, transactions without opening of the account, transactions with a bank account (P.A. Tamarov \& M.A. Mikhailova, 2012, p. 32). The function of money as store of value has got significant potential for implementation in payment systems, accumulating balance of accounts. On card credit and other transferable accounts at call, there is always some transit transaction balance of funds, which considering bookkeeping principle of continuity of operations) acts as demand deposit, substituting loan capital and regulating the liquidity. As the payment system accelerates its activity, the volume of money would increase and financial benefit proportionally increases, which acts as tangible demonstration of means of the hoarding function. Money, circulating within the payment system, is transformed into capital, or according to G.B. Polyak's opinion - 'into active money wealth'. (Finance. Monetary circulation. Credit, 2008, p. 18). Success of means of the hoarding function and engaging additional funds into production economic turnover would depend on dynamics of unification and standardization of transactions within digital economics.

\section{Money as standard of value}

The money function as standard of value during innovation of money turnover doesn't greatly transform its content, because evaluating itself is either outside the infrastructure of payment systems, or channels are only 'shell' of evaluation processes that go inside. Derived meaning of this function and its relation with money turnover is proved by money definition, represented by K. Marks and F. Engels: 'money is commodities, functioning as standard of value and that is why performing (directly and indirectly via substitutes) and function as medium of exchange' (K. Marks \& F. Engels, 1960, p. 140).

Evaluation of value peculiarities is demonstrated via functioning of so called 'private money', the founder of this theory is F.A. Hayek (Hayek, Friedrich August van, 1996). Evolution of private money within modern payment systems result became digital currency, stipulating exchanging for official units of currency entering and exiting system. Measuring is this case is reduction to a common denominator of commodities, works and services, paid or rendered within payment service. Placed to individual account in the payment service cash and non-cash (credit) money is exchanged into fixed amount of natural units of the service or certain amount of conventional payment units of value, issued within payment service, representing the pre-paid value (V. $Y u$. Kopytin, 2010, pp. 48-49). This value has got the same scope and usefulness as money, that money exchanged into it, that means that not value itself has transformed, but payment instrument, representing it.

To be the adequate evaluation tool, money and payment tools must have the equal ranking liquidity. From one side real money at the entrance of payment service (payment system) are absolutely liquid, but their derived equivalents inside payment service (payment system) within public understanding lose its asset due to 'dilution' of the security basis. From the other side the main condition of acknowledgement of money as liquidity is in warranted safety of their value. In crisis conditions weak currency would definitely lose value, and if the guaranteed payment system is reliable tools issued within payment service, bind to stronger currency can withstand loss of value. Considering the obvious subjectivism at liquidity and risks evaluation, connected with its loss, we'll agree with L.N. Krasavina opinion that money detect, evaluate values having no own value. (L. N. Krasavina, 2001, p. 5). As payment services and payment systems develop this idea is proved again and again.

Further we'll investigate the derived functions of money and their interpretation in economy digitalization.

\section{Information function of money}

Information function, demonstrated is getting 'detailed information on mass, structure, velocity of money turnover and the economic condition in general' (O. M. Korobeynikova et al, 2017), it is actualized according to level of institutional, technological and instrumental development of money turnover. Integration of information function into matrix (picture 1) shows analogue dynamic in changing specifications of this money function depending on level of money turnover digitalization. For this purpose into matrix are introduces indexes $i$ and $v^{i}$.

The lower segments (2 and 4) (absence of initial development of payment systems and payment services) specify the information function via conventional ways and instruments of cash and non-cash settlements and provide information on duration of money keeping within channels.

Segment 2 is specified by poor information during functioning of money as medium of payment in the conditions of pre-payment and in conditions of post-payment (scope of information from 0 to min values depending on information status: illegal hidden or accounted transparent). The velocity of information about payments in the poor development of money turnover environment and respective money as 
information about payment providers turnover velocity in the condition of following payment (considered only payment itself Д, made after commodities movement in the formula T...fK(t)...t...Д), can be considered conditionally constant (with the level, tending towards pre-payment index) $\left(\mathrm{v}^{\mathrm{i}}=\right.$ const). Respective consistency is explained by standardization of variants of relation for transfer of money as payment. In the pre-payment environment, the velocity of information flow has minimal values $\left(\mathrm{v}^{\mathrm{i}} \rightarrow \mathrm{min}\right)$, the sum of money transfer velocity from the payer to the payee (via agents or transfer itself) (within time period $t$ ) and velocity of information about delay movement $\mathrm{fK}(\mathrm{t})$ along all stages of pre-payment formula Д...fK $(\mathrm{t}) \ldots \mathrm{t} . . \mathrm{T}$.

Segment 4 demonstrates the information function as money performs the function of medium of exchange within the poor currency circulation environment. From the currency circulation point of view, post-payment and pre-payment in this environment would have the same information flow that is in wide range from minimal values while use cash to maximal values at use of non-cash payment instruments ( $\mathrm{i}=$ [Min; Max]). For post-payment and pre-payment there would be the same information flow velocity according to respective stages Т...t..Д and Д...t...Т, use in the circulation process without exception. Information transfer velocity about money turnover depends on conditions of payment and used forms of settlement and is $\mathrm{v}^{\mathrm{i}}$ index, tending to maximal value $\max _{0}$, restricted by the factor of poor payment systems development $\left(\mathrm{v}^{\mathrm{i}} \rightarrow \max _{0}\right)$.

Payment systems develop quantity and quality that is shown in upper segments; the served money flows become informative flows due to substitution of cash by non-cash (including electronic) payment means that can act as data medium for not only money and value, but any other information (digital currency).

Within segment 1 of the matrix, the scope of information flow about payment tends to maximal values, restricted only by technological factors (effecting payment method) for each stage of payment infrastructure of money turnover development (i $\rightarrow$ Max). The possibility to process greater volumes of information about payments object of the studied function is reasonably explained by growth of information transfer velocity and payment itself. Minimal velocity of information transfer in poor developed money turnover environment and being a relatively constant value (at the left lower segment of matrix, the post-payment $\mathrm{v}^{\mathrm{i}}=$ const and prepayment $\mathrm{v}^{\mathrm{i}} \rightarrow \min$ ) becomes greater and gets the upper limit $\left(\mathrm{v}^{\mathrm{i}} \rightarrow \max _{1}\right.$ with $\left.\max _{1}>\max _{0}\right)$, equal to money transfer velocity within the function of medium of exchange that proves approaching of two basic functions of the matrix. An innovative feature of modern digital technologies (for example, application of 'blockchain' technology) allows getting not only set quantity parameters of information, but its qualitative specifications (visibility, verifiability, legality and other) (D. A. Kochergin, 2006), (R. Yu. Skokov, 2013).

Segment 3 demonstrates the money function of medium of exchange and is specified by the greatest approaching of 'money' and 'information' ideas as pre-payment and post- payment. In the information function of money environment, the right upper segment is alike with the left upper segment as for scope of information flow, generated and transferred during exchange process $(\mathrm{i} \rightarrow$ Max), and for maximal velocity of information about money flow transfer $\left(v^{i} \rightarrow \max _{1}\right.$ with $\left.\max _{1}>\max _{0}\right)$. The information function in both segments is alike; the differences become in basic specifications of money functions as medium of payment and medium of exchange.

Revealing of common factors and their dynamics let us speak about diffusion of the information function of money and classical functions of medium of payment and medium of exchange because of transformation of material forms of money into immaterial form.

\section{Productive function of money}

The productive function of money joints characteristics of earlier demonstrated money functions and is in money functioning optimization, initially expressed via growth of index of performance - velocity of money at different stages of economy.

Productivity in economics (at its broad sense) is specification of efficiency of any business economy, expressed by scope of commodities and services, made for each unit of expenses of used or consumed resources. Typically the aggregate growth of productivity is connected with increasing of productivity of labor as one of the production factors. According to the widespread definition of currency circulation ('Currency circulation is financial motion into internal business volume in cash and non-cash form, serving the selling of commodities, as well as noncommodities payments and settlements in economy' (Monetary and Financial System, 2016), the productivity of modern money, circulating into payment systems, is expressed by velocity of money in the circulation of income and payment circulation, duration (velocity) of non-cash circulation of in macroeconomics, mezoeconomics and macroeconomics, monetization of economics (index of tightening up of funds within turnover of gross domestic product) (G.G. Gospodarchuk, 2006). The productive function of money expressed in its ability to generate growth of the indicated indexes contributed to the digital innovation of currency circulation. It depends least on influence of the same factors, which provide growth of productivity in economics in general, that is: the investments, innovations, assimilation of techniques, education, influence of state via monetary, fiscal policies and other. So, as digital economy develops in quality and quantity, the production function of money becomes actual.

\section{Regulating function of money}

The regulating function of money is influence of conductive means to acceleration of currency circulation of businesses and economics in general on decreasing needs of payment transaction in cash and non-cash in condition of money tools. The regulating function as well as productive is 'incorporated' with traditional functions of money as means of payment and medium of exchange. The regulating influence of money is done via transmission of money flows, circulating 
while serving economic relations (for payments as well as for money circulation) via payment systems according to the regulations set by the state in a certain historic period within the money and credit policy. Thus we can declare that those modern payment systems, being the organization and technological environment for money and money equivalents circulation, can be used as an additional, accessary tool of money and credit policy (to the main conventional tools), detecting the regulative function of circulating money.

\section{Institution function of money}

The institution function of money is in its revolutionary influence on the institutional state of economy, the society ability to progress, form digital economy and that is why it is connected with dynamics of innovations not only in currency circulation environment, but in all spheres of social and economic life of society (Diana Dmitrievna Burkaltseva, Olga Sergeevna Sivash, Oleg Valerievich Boychenko, Lyubov Vasilievna Savchenko, Tatyana Nikolaevna Bugaeva, Snezhana Anatolyevna Zotova, 2017). Payment systems act as one of the main conductors, transmission devices of digital innovations implementation. But payment innovation can become threat for certain institutional elements of modern society. So 'block' technologies of data transfer (for example, 'blockchain' technologies) need no agent for transfer of information and money transactions and need no finance and other institution agents. It is understandable that paradoxes of money institution functions should be studied separately within historical perspective.

\section{CONCLUSION}

Digital technologies of currency circulation, money and money tools evolution, development of the payment institutional infrastructure changed functioning of cash and especially non-cash currency circulation. The main factor, influencing the changes in currency turnover and specification of money functions, became the time of money stay (static) within payment systems channels and the time of movement (dynamic) of money along these channels.

The revealed trends and their dynamics provide information on mutual diffusion of classical money functions as means of payment and means of exchange and derived functions due to transformation of material form of money into immaterial information (digital) form. The money functions are not constant and can be changed from time to time under the influence of innovations, conducted by payment infrastructure elements.

\section{Acknowledgment}

The research was financially supported by the Russian Foundation for Basic Research (RFBR) and the Administration of the Volgograd Region according to the project "Modernization of Payment Infrastructure and Development of Innovative Payment Services in the Region (by the Example of the Volgograd region)", No. 17-12-34037.

\section{References}

[1] M.L. Bech, C. Preisig, K. Soramaki(2008), Global Trends in LargeValue Payment, FRBNY Economic Policy Peview.

[2] D.D. Burkaltseva, O.V. Boychenko, O.S. Sivash, N.M Mazur, S.A. Zotova, A.V. Novikov. (2017), "The Construction of the Digital Organizational. Social and Economic Production Mechanism in the Agro-industry”, European Research Studies Journal, Volume XX, Issue 4B, pp. 350-365.

[3] D.D. Burkaltseva, O.S. Sivash, O.V. Boychenko, L.V. Savchenko, T. N. Bugaeva, S.A. Zotova, 2017, "Realization of Investment Processes in the Agricultural Sector of the Digital Economy", European Research Studies Journal, Volume XX, Issue 4B, pp. 366-379.

[4] V.A. Chelnokov, "K voprosu o suschnosti, funktsiyah $\mathrm{i}$ roli sovremennyh deneg", [To the Issue of the Essence, Functions and Role of Modern Money], 2010, Money and Credit, 5, 68-70.

[5] E. J. Dolan, D. Lindsay (1994), Macroeconomics, Saint Petersburg, Litera plyus, pp. 668.

[6] Finance, Monetary circulation, Credit: Manual. In by G.B. Polyak (Eds.), (2008), Moscow : YUNITI-DANA, pp. 528.

[7] G.G. Gospodarchuk, (2006), "Den'gi dlya rossijskoj ehkonomiki", [Money for the Russian economy], Money and Credit, 12, 29-33.

[8] Hayek, Friedrich August van. (1996), Private money, Moscow: The Institute Of National Economy Model, pp. 229

[9] V.I. Ionov (2010), "Razvitie nalichnogo denezhnogo obrashheniya v usloviyakh krizisa" [Development of cash circulation in a crisis] Money and Credit, 1, 21.

[10] J.M. Keynes, "General theory of employment, interest and money", 1999, Moscow: Gelios, pp. 352.

[11] O.M. Korobeynikova, D.A. Korobeynikov (2015). "The problems of the transmission of monetary and credit resources in the context of monetary policy", [Problemy transmissii denezhnykh i kreditnykh resursov v kontekste provedeniya denezhno-kreditnoi politiki] Proceedings of the lower Volga agrodiversity complex: science and higher professional education. 2(38), 246-251

[12] D.A. Kochergin, "Elektronnye den'gi: organizatsiya ehmissii, provedenie platezhej, regulirovanie denezhnogo oborota" [Electronic money: organization of issue, payments, regulation of money circulation] 2006, Saint Petersburg: Saint Petersburg state University of Economics and Finance/

[13] V.Yu. Kopytin "Novye tendentsii $\mathrm{v}$ razvitii roznichnyh platezhnyh uslug", [New Tendencies in Developing Retail Payment Services] 2010, Calculations and Operational Work in Commercial Bank, 1, 28-34.

[14] O.M. Korobeynikova, D.A. Korobeynikov, L.V. Popova, O.V. Savina, R.S. Kamilova, "The current state of the payment infrastructure and development of payment systems in Russia and the Volgograd region", 2017, Espacios, Volume 38, Issue 62/ URL: http://www.revistaespacios.com/a17v38n62/17386211.html (accessed 29.12.2017)

[15] A.M. Kosoj, "Platezhnyj oborot: issledovanie i rekomendatsi" [Payment transactions: a study and recommendations], 2005, Moscow: Finance and statistics.

[16] L.N. Krasavina, "Problemy deneg v ehkonomicheskoj nauke" [The problem of money in Economics], 2001, Money and credit, 10. 3-6.

[17] K. Marks, "Criticism of political economy", Capital, Vol.1. Moscow : Publishing house 'Tekhnologii razvitiya', 2013, pp. 1200.

[18] K. Marks, F. Engels, Compositions, vol. 23.- Moscow: Gospolitizdat, 1960, pp. 907

[19] Monetary and Financial System: Manual, in by M.A. Abramova, E.V Markina, (Eds.), 2016, Moscow: KNORUS, pp. 446.

[20] Money, credit, banks: Manual. In by V.V. Ivanov, B.I. Sokolov, (Eds.), 2003, Moscow: TK VELBI, Publishing house Prospect, pp. 624.

[21] Money, credit, banks: Manual. In by E.F. Zhukov. (Eds.), 2009, Moscow: YUNITI-DANA, pp. 783.

[22] A.V. Nemchenko, T.A. Dugina, E.A. Likholetov, A.V. Malofeev, an A.A. Likholetov, "Conditions for developing sustainable growth of 
region's agricultural industry", International Journal of Economics and Financial Issues, 2016, 6, 2, 207-211.

[23] A.S. Ovchinnikov, A.N. Tseplyaev, N.N. Balashova, E. Šilerová, and V.A. Melikhov, "Monitoring of Integrated Accounts Rendering and Non-Financial Information Disclosure to Agricultural Holdings (on the Basis of the Volgograd Region)", Agris on-line Papers in Economics and Informatics, 2014, 6, 4, 89-100.

[24] P. Samuelson, Economics, Volume 2, Moscow: NPO “ALGON” VNIIS "Engineering», 1993, pp. 416.

[25] A.S. Selishchev, Money, credit, banks: Course of lectures, 2012, Retrieved from http:// www.selishchev.com (Date of access 18.06.2012).

[26] S.K. Semenov, 2006, "Den'gi: ehvolyutsiya, sovremennye vidy i klassifikatsiya", [Money: the evolution of modern types and classification], Finance and credit, 12, 29-34
[27] R.Yu. Skokov, Vvedenie v teoriyu rynkov «addiktivnykh blag» [Introduction to the theory of markets of "addictive goods»] Modern economy: problems and solutions, 5 (41), 2013, 13-20.

[28] J.E. Stiglitz, A. Bhattacharya, "Underpinnings for Stable and Equitable Global Financial System", 1999, N.-Y.: World Bank.

[29] P.A. Tamarov, M.A. Mikhailova, "Razvitie roznichnyh platezhnyh uslug: ot platezhnyih servisov $\mathrm{k}$ uslugam platezhnoy sistemy", [Development of Retail Payment Services: from Payment Services to Services of Payment Systems], 2012, Money and Credit, 9, 31-39.

[30] V.M. Usoskin, "Sovremennye tendentsii razvitiya platezhnyh sistem. Finansovye instituty i ekonomicheskoe razvitie", [Modern Tendencies of Payment Systems Development. Financial Institutes and Economic Development], 2006, Moscow: IMEMO, pp. 428. 